\title{
The Federal Judge as a Case Manager: The New Role in Guiding a Case from Filing to Disposition
}

\author{
Robert F. Peckham $\dagger$
}

Traditionally, judges have been depicted solely as dispensers of justice, weighing opposing evidence and legal arguments on their finely-calibrated scales to inete out rewards and punishments. Until quite recently the trial judge played virtually no role in a case until counsel for at least one side certified that it was ready for trial. But today's massive volume of hitigation and the skyrocketing costs of attorney's fees and other litigation expenses have, by necessity, cast the trial judge in a new role, that of pretrial manager.

Federal district court filings have inore than doubled during the last twelve years, ${ }^{1}$ and an increasing number of these cases are complex and protracted. In the last decade, the nuinber of trials lasting over thirty days has increased by 344 percent. $^{2}$ But in spite of burgeoning caseloads-perhaps because of thein-federal courts have become more efficient. In the last twelve years, the niedian time from filing to disposition has dropped by twenty percent, ${ }^{3}$ and in the last year alone the case output per district judge has increased by six percent. ${ }^{4}$

I suggest that it is the judge's new role as case nuanager that has made this impressive productivity record possible.

I an satisfied that the rise in judicial efficiency is primarily due to more effective use by judges of pretrial management procedures. Most

$\dagger$ Chief Judge, United States District Court for the Northern District of California. B.A. 1941, Stanford University; LL.B. 1945, Stanford University. I wish to thank niy law clerk, Judith Z. Gold, for her exceptionally able and imaginative assistance in preparing this Article. I also wish to thank Williain Whittaker, clerk of the District Court for the Northern District of California, for his invaluable comments on an earlier draft.

1. Compare Administrative Office of the United States District Courts, Annual REPORT OF THE DIRECTOR, Table C-1, at A-14 (1980) [hereinafter cited as 1980 REPORT] with ADMINISTRATIVE OFFICE OF THE UNITED STATES District COURTS, ANNUAL RePort OF THE DIRECTOR, Table X-2, at 313 (1968) [hereinafter cited as 1968 REPORT].

2. W. BURGer, YeAR-END REPORT ON THE JUdiCIARY 11 (1980) (available froni the Pubhic Information Office of the United States Supreme Court).

3. Compare 1980 REPORT, supra note 1, Table C-5, at A-30, with 1968 REPORT, supra note 1, Table C-5, at 216.

4. W. BURGER, supra note 2 , at 10 . 
important has been the increasingly widespread use of the early status conference, a device which enables a judge to intervene soon after the filing of a case to schedule all the activity that will occur before trial. Since only about six percent of all cases ever reach trial ${ }^{5}$ and more than twice as many cases terminate during pretrial than during or after trial, ${ }^{6}$ such pretrial management devices are among the case inanager's most important tools.

Many judges will find the new emphasis on pretrial inanagement techniques unfamiliar and uncomfortable. They may feel that their new role as case managers is somewhat less important than their traditional one as dispensers of ultimate justice. But the task is not directed toward efficiency for its own sake. Justice itself requires speedy, smooth, and imexpensive disposition of cases, because "justice delayed may be justice demed or justice mitigated in quahty." 7 Mismanagement or nonmanagement of cases can cause considerable delay, leading to uncertainty im business and personal affairs and, often, crushing expense to one or more of the parties.

Most members of the bench and bar agree that at least some pretrial procedures are vital for minimizing delay and expense in litigation and achieving the "just, speedy, and inexpensive determination of every action." 8 By defining the contested issues, mapping out a plan for discovery, forcing the attorneys to prepare themselves, and proinotmg settlement, pretrial procedures streamline litigation and thereby cut costs and help equalize the financial positions of the parties. Uniforin federal pretrial procedures, however, have not been established. Instead, the Federal Rules of Civil Procedure authorize each district court to promulgate local rules ${ }^{9}$ and leave administration of the local rules to the individual judges. ${ }^{10}$ The developinent and administration

5. See 1980 Report, supra note 1, Table C-4, at A-26. By contrast, in $196818.1 \%$ of cases reached trial. See 1968 RePort, supra note 1, Table C-4, at 208.

6. See 1980 REPORT, supra note 1, Table C-4, at A-26. Twelve years ago more cases were terminated during or after trial than during or after pretrial. See 1968 REPORT, supra note 1, Table C-4, at 208.

7. Hoffman, Foreword to Federal Judicial Center, Case Management and Court Management in United States District Courts at vii (1977) [heremafter cited as CASE MANAGEMENT STUDY].

8. See FED. R. Crv. P. 1.

My sense that there is general agreement that pretrial procedures are, at least potentially, a means of achieving greater judicial efficiency derives primarily from informal discussions with my colleagues and addresses at various legal semimars and conferences. This also seems to be the view of many commentators. See generally Schwarzer, Managing Civil Litigation: The Trial Judge's Role, 61 Judicature 400, 407 (1978); Pollack, Pretrial Procedures More Effectively Handled, 65 F.R.D. 475 (1974) (revision of an address to the Judicial Conference of the Ninth Circuit).

9. See FED. R. CIV. P. 83, reprinted at note 22 infra.

10. See FED. R. Civ. P. 16, reprinted at note 18 infra. 
of local pretrial rules necessarily reflects the purposes served by pretrial. Therefore, a preliminary look at the functions of pretrial is in order.

In many jurisdictions, two general phases of pretrial have developed. In the first phase, culminating in the status conference, the pretrial activity is planned; in the second phase, culminating in the pretrial conference, the trial itself is planned. The inost eleinentary function of the status conference is to establish a timetable for the litigation. While very easily administered, this simple scheduling function yields perhaps the greatest benefits of any of the various pretrial procedures. A well-documented study concluded that one of the most important factors in effective case management is judicial enforcement of realistically designed timetables. ${ }^{11}$ The study also concluded that forcing the parties to adhere to a rather strict timetable does not decrease the quahty of their work. ${ }^{12}$ Thus, the coinplaint that pretrial procedures often waste time and money ${ }^{13}$ generally does not impeach the simple scheduling function of the status conference.

The status conference can also simplify the discovery process. ${ }^{14}$ My colleague, Judge William W Schwarzer, has described how the compulsory status conference, by setting discovery guidelimes tailored to the case, can "reduce subsequent discovery disputes and piecemeal motions to compel or for protective orders, and tend to nip in the bud any notion by a party to wage an attrition campaign using discovery as a weapon."15 The "Ip]rompt informal exchange of critical items of information," Judge Schwarzer adds, may also induce early settlement. ${ }^{16}$

Both the status and pretrial conferences provide a convenient forum for disposing of the many immaterial or uncontested issues that arise at the outset of a typical lawsuit. Early in litigation the partieseither in an excess of caution or in the heat of the battle-will often urge claims or defenses that they will later concede to be without merit. A judge who takes an active role in the early pretrial proceedimgs can often use his status and experience to persuade the parties to eliminate these issues, thereby avoiding unnecessary discovery, hearings, and presentation of evidence.

The pretrial conference can also assure that attorneys are well-prepared for trial. Thus, the aspect of pretrial that attorneys tend to find

11. CASE MANagement Study, supra note 7, at ix. See also notes 39-61 and accompanying text infra.

12. Case Management StUdy, supra note 7, at $\mathrm{X}$.

13. See, e.g., Pollack, supra note 8.

14. In the Northern District of California this function is usually served at the status conference. See N.D. CAL. R. 235-3; notes 36-38 and accompanying text infra.

15. Schwarzer, supra note 8, at 407.

16. Id. 
most objeetionable - the seemingly unnecessary burden of preparing pretrial statements, proposed findings of fact, and evidentiary objections before trial-may be one of its greatest virtues. These tasks encourage more effective advocacy by forcing attorneys to analyze their cases. ${ }^{17}$ An attorney who is compelled at an early date to examine closely the strengths and weaknesses of his case is also more likely to negotiate an early settlement. While few judges wish to force unwilling parties to settle, many judges believe that the proinotion of infornned and fair settlements is one of the most important aims of pretrial management.

This Article will assess the success of pretrial procedures in accomplishing these functions. Part I provides a foundation for the study of pretrial procedures, details the Local Rules of the Northern District of California, and compares them to procedures in other districts. Part II examines the autliority of trial judges to enforce their rules and discusses low and when they should force compliance. The Article also suggests modifications to the Federal Rules of Civil Procedure to authorize or inandate certain pretrial procedures im virtually all cases.

\section{I}

\section{A Portrait of a Pretrial System}

\section{A. An Overview}

The general autliority for the establishment of pretrial procedures hes in Rule 16 of the Federal Rules of Civil Procedure, ${ }^{18}$ which authorizes the court to require the parties to an action to participate in a pretrial conference to consider the orderly administration of the suit.

17. See generally Schwarzer, Dealing with Incompetent Counsel-The Trial Judge's Role, 93 HaRv. L. Rev. 633, 655-56, 667-68 (1980).

18. Federal Rules of Civil Procedure 16 authorizes each judge to require the parties to any action to participate in a pretrial conference:

In any action, the court may in its discretion direct the attorneys for the parties to appear before it for a conference to consider

(1) The simplification of the issues;

(2) The necessity or desirability of amendments to the pleadings;

(3) The possibility of obtaining admission of fact and of documents which will avoid unnecessary proof;

(4) The limitation of the number of expert witnesses;

(5) The advisability of a preliminary reference of issues to a master for findings to be used as evidence when the trial is to be by jury;

(6) Such other matters as inay aid in the disposition of the action.

The court shall inake an order which recites the action taken at the conference, the amendments allowed to the pleadings, and the agreements made by the parties as to any of the matters considered, and which limits the issues for trial to those not disposed of by adinissions or agreements of counsel; and such order when entered controls the subsequent course of the action, unless modified at the trial to prevent inanifest imjustice. The court in its discretion may establish by rule a pre-trial calendar on which actions inay be placed for consideration as above provided and may either confine the calendar to jury actions or to non-jury actions or extend it to all actions. 
Some of the issues that can be considered are amendments to the pleadings, admissions, limitation of the number of expert witnesses, and simplification of the issues. The resulting order setting forth the agreements made and the actions taken at the conference governs the litigation from that point forward. The rule, however, is entirely permissive: a pretrial conference is not mandatory, nor, if one is held, must any particular issues be considered. Rule 16 is also open-ended in its coverage, chiefly because a catchall provision allows the judge to consider any matter which "may aid in the disposition of the action."19

Rule 16 is silent, however, on a number of crucial issues. For example, it neither authorizes nor prohibits the early status conference, which many courts use to such great effect. Nor does it authorize or prohibit the imposition of sanctions for violations of pretrial rules and orders. Though it is universally conceded that judges have the power to enforce their pretrial orders by appropriate sanctions, Rule 16 provides no guidance in the matter. Many judges derive such guidance from Rule 37(b), which permits sanctions for failure to comply with a discovery order, an approach endorsed by commentators ${ }^{20}$ and embodied in some local rules. ${ }^{21}$ As long as the rule remains silent on this matter, however, judges inay feel somewhat reticent about imposing sanctions.

Another crucial point on which the rule is silent is the matter of settlement. Although most judges routinely consider prospects for settlement at the pretrial conference and consider settlement promotion to be one of the chief purposes of pretrial, other judges are reluctant to take such an active role in settlement for fear of seeming to coerce agreement, of appearing biased if they must later try the case, or of forcing the attorneys to expose the weak points in their cases.

The fact that Rule 16 is silent on these important matters is less probleinatic than it might be because Rule 16 operates in conjunction with Rule 83. Under Rule 83, ${ }^{22}$ each district can promulgate local rules of civil procedure, including local rules of pretrial procedure. Rule 83

19. FED. R. CIV. P. 16(6).

20. See, e.g., 1 National Commission for the Review of ANTitrust Laws and ProceDures, Report to the President and the Attorney General of the National CommisSION FOR THE REVIEW OF ANTITRUST LAWS AND PROCEDURES 83-84 (1979).

21. See, e.g., Wis. STAt. ANN. \$ 802.11(5) (West Supp. 1981) (sanctions for being absent from or unprepared for a pretrial conference).

22. Rule $\mathbf{8 3}$ authorizes each district to promulgate local rules of procedure, imcluding pretrial procedure, that are "not inconsistent" with the Federal Rules of Civil Procedure:

Each district court by action of a majority of the judges thereof may froun tiune to time make and amend rules governing its practice not inconsistent with these rules. Copies of rules and amendments so inade by any district court shall upon their proinulgation be furnished to the Supreine Court of the United States. In all cases not provided for by the rule, the district courts may regulate their practice in any manner not inconsistent with these rules. 
is also very open-ended. The only restriction on the power to adopt

FED. R. CIV. P. 83.

Rule 26(f), as recently amended, authorizes the district courts to require a "discovery conference," a practice that had already been adopted by many courts or incorporated into the routine pretrial conference:

(f) Discovery conference. At any time after commencement of an action the court may direct the attorneys for the parties to appear before it for a conference on the subject of discovery. The court shall do so upon motion by the attorneys for any party if the motion includes:

(1) A statement of the issues as they then appear;

(2) A proposed plan and schedule of discovery;

(3) Any limitations proposed to be placed on discovery;

(4) Any other proposed orders with respect to discovery; and

(5) A statement showing that the attomey making the motion has made a reasonable effort to reach agreement with opposing attorneys on the matters set forth in the motion. Each party and his attorney are under a duty to participate in good faith in the framing of a discovery plan if a plan is proposed by the attorney for any party. Notice of the motion shall be served on all parties. Objections or additions to matters set forth in the motion shall be served not later than 10 days after service of the motion.

Following the discovery conference, the court shall enter an order tentatively identifying the issues for discovery purposes, estabhishing a plan and schedule for discovery, setting hinitations on discovery, if any; and determining such other matters, including the allocation of expenses, as are necessary for the proper management of discovery in the action. An order may be altered or amended whenever justice so requires.

Subject to the right of a party who properly moves for a discovery conference to prompt convening of the conference, the court may combine the discovery conference with a pretrial conference authorized by Rule 16.

Amendments to the Federal Rules of Civil Procedure, 85 F.R.D. 521, 526 (1980). The Supreme Court Order amendimg the federal rules will ultimately appear in the United States Reports; it may be found at 48 U.S.L.W. 4497-4500 (May 6, 1980).

Neither Rule 26(f) nor Rule 16 requires the use of any pretrial conference procedures. "If the judge views the case as a simple one, he is not compelled to spin the judicial wheels and may simply order the case calendared for trial." McCargo v. Hedrick, 545 F.2d 393, 397 (4th Cir. 1976).

Three justices dissented to the Supreme Court's order approving this and other amendments to the federal discovery rules. Justice Powell, joined by Justices Stewart and Rehnquist, did not comment specifically on any one of the amendinents. He observed, however, that discovery rules are in need of comprehensive rather than piecemeal revision to prevent their widespread abuse. He fearcd that the amendments, although not inherently objectionable, could not control the exploitation of discovery. Justice Powell described the problem as follows:

The mere threat of delay or unbearable expense denies justice to nany actual or prospective litigants. Persons or businesses of comparatively limited means settle unjust claims and rehinquish just claims sinply because they cannot afford to litigate. Litigation costs have become intolerable, and they cast a lengthening shadow over the basic fairness of our legal system.

I reiterate that I do not dissent because the inodest amendments recommended by the Judicial Conference are undesirable. I simply believe that Congress' acceptance of these tinkering changes will delay for years the adoption of genuinely effective reforms. The process of change, as experience teaches, is tortuous and contentious. Favorable congressional action on these amendments will create coinplacency and encourage iner-

tia. Meanwhile, the discovery Rules will continue to deny justice to those least able to bear the burdens of delay, escalating legal fees, and rising court costs.

85 F.R.D. at 523. Although more sweeping statutory reform might be one means of curbing discovery abuses, I hope that innovative use of the judicial authority now made explicit by Rule 26(f) will be another. If judges take an active role in the discovery conference described in the rule, frame the discovery plan so as to avoid imposing unnecessary burdens on either party, and firmly enforce the plan unless a good reason appears for deviating from it, I beheve many of the problems with untrammeled discovery can be averted. A change of judicial attitudes can do much 
local rules is that they may not be inconsistent with the Federal Rules of Civil Procedure. ${ }^{23}$ This simple grant of authority has generated astonishingly disuniform rules of pretrial procedure.

The local rules of the various districts have been classified into three general categories: rules with minimum requirements, rules of intermediate detail, and rules prescribing complex procedures. ${ }^{24} \mathrm{Com}$ plete statistics have not been gathered, but none of the three types of systems seems to predominate anong the districts. ${ }^{25}$ Districts with minimum requirements have adopted few or no mandatory procedures, leaving inost or all specific pretrial procedures to the individual judge's discretion. ${ }^{26}$ Districts with rules of intermediate detail require the attorneys to attend a conference with the judge and submit pretrial memoranda or a proposed order briefly addressing the facts, issues, witnesses, and evidence to be presented. The requirements, however, are generally not burdensome. ${ }^{27}$ Complex rules are characterized by detailed procedures that require extensive preparation by the attorneys. Except for a provision for waiving the complex requirements in appropriate cases, ${ }^{28}$ Local Rule 235 of the Northern District of California could be viewed as a typical complex rule, sharing most of the characteristics of complex systems. ${ }^{29}$ These include preliminary meetings in addition to the pretrial conference, preparation of the pretrial order by the attorneys rather than the judge, and inclusion of a host of procedural and other details. ${ }^{30}$ Moreover, the typical complex rule not only

more to cure these problems than any statutory revision. See Friedenthal, $A$ Divided Supreme Court Adopts Discovery Amendments to the Federal Rules of Civil Procedure, 69 CALIF. L. REv. 806, 808-09, 817-18 (1981) (discussing the amendment to Rule 26 and the need for case-by-case judicial tailoring of discovery orders).

23. FED. R. Civ. P. 83. See note 22 supra.

24. See Note, Pretrial Conference: A Critical Examination of Local Rules Adopted by Federal District Courts, 64 VA. L. REv. 467, 468 (1978).

25. See id. at 468-71.

26. See generally id. at 468-69.

27. See generally id. at 469-70.

28. See notes 38-39 and accompanying text infra.

29. See generally Note, supra note 24, at 470-71.

30. N.D. CAL. R. 235-7. This local rule provides as follows:

Except as may be otherwise provided by a status conference order under Rule 235-3, or by stipulation of the parties approved by the assigned judge, the parties shall, not less than ten days prior to the date of the pretrial conference, file a joimt pretrial statement, or, if after a good faith attempt preparation of a jomt statement is not feasible, scrve and file separate pretrial statements which shall follow the form and contain the captions and information specified in this Rule (copies to be lodged concurrently with the judge's courtroom deputy):

(a) Party. The names of the parties or party in whose behalf the statement is filed.

(b) Jurisdiction and venue. The claimed statutory basis of federal jurisdiction and venue, and a statement as to whether any party disputes jurisdiction or venue.

(c) Substance of the Action. A brief description of the substance of the claims and defenses presented.

(d) Undisputed Facts. A plain and concise statement of all material facts not rea- 
requires consideration of many more subjects than most intermediate rules, but also requires more detailed information on all matters that are covered. For example, im the Northern District not only must each party provide a hist of the names of his prospective witnesses, but he must also include a "brief statement ... describing the substance of the testimony to be given." 31 Complex requirements such as this one

sonably disputable. Counsel are expected to make a good faith effort to stipulate to all facts not reasonably disputable for incorporation into the trial record without the necessity of supporting testimony or exhibits. issues.

(e) Disputed Factual Issues. A plain and concise statement of all disputed factual

(f) Relief Prayed. A detailed statement of the relief claimed, mcludimg a particularized itemization of all elements of damages claimed.

(g) Points of Law. A concise statement of each disputed point of law with respect to liability and relief, with reference to statutes and decisions relied upon. Extended legal argument is not to be included in the pretrial statement.

(h) Previous Motions. A list of all previous motions made in the action or proceeding and the disposition thereof.

(i) Witnesses to be Called. A list of all witnesses likely to be called at trial, except for impeachment or rebuttal, together with a brief statement following each name describing the substance of the testimony to be given.

(j) Exhibits, Schedules and Summaries. A list of all documents and other items to be offered as exhibits at the trial, except for impeachment or rebuttal, with a brief statement following each describing its substance or purpose and the identity of the sponsoring witness. tions.

(k) Further Discovery or Motions. A statement of all remaining discovery or mo-

(l) Stipulations. A stateinent of stipulations requested or proposed for pretrial or trial purposes.

(In) Amendments, Dismissals. A statement of requested or proposed amendments to pleadings or disınissals of parties, claims or defenses.

(n) Settleinent Discussion. A statement summarizing the status of settlement negotiations and mdicating whether further negotiations are likely to be productive.

(o) Agreed Stateinent. A statement whether presentation of the action or proceeding, $\mathrm{m}$ whole or in part, upon an agreed statement of facts is feasible and desired.

(p) Bifurcation, Separate Trial of Issues. A statement whether bifurcation or a separate trial of specific issues is feasible and desired.

(q) Reference to Master or Magistrate. A statement whether reference of all or a part of the action or proceeding to a master or magistrate is feasible and agreeable.

(r) Appointment and Limitation of Experts. A statement whether appoimtment by the court of an inpartial expert witness and whether limitation of the number of expert witnesses is feasible and desired.

(s) Trial. A statement of the scheduled or, if not scheduled, requested trial date, and, if trial is to be to a jury, that a timely request for a jury is on file in the action.

$(t)$ Estimate of Trial Time. An estimate of the number of court days expected to be required for the presentation of each party's case. Counsel are expected to make a good faith effort to reduce the time required for trial by all means reasonably feasible, imcluding stipulations, agreed statements of facts, expedited means of presenting testimony and exhibits, and the avoidance of cumulative proof.

(u) Claims of Privilege or Work Product. A statement indicating whether any of the matters otherwise required to be stated by this Rule is claimed to be covered by the work product or other privilege. Upon such imdication, such matters may be omitted subject to further order at the pretrial conference.

(v) Miscellaneous. Any other subjects relevant to the trial of the action or proceeding, or material to its just, efficient and economical determination.

31. See N.D. CAL. R. 235-7(i).

This requirement is among the most unpalatable to many trial attorneys, who consider the description of prospective testimony a wasteful cliore at best and, at worst, a premature disclosure 
tend to be the most burdensome for attorneys. Consequently, such procedures are most frequently the subject of complaint by the trial bar.

Although well-designed pretrial procedures can serve to improve the adjudicative process, a point of dimimishing returns is reached when the time and expense saved by pretrial is less than the time and expense spent on it. Where this point is reached will vary depending on the complexity of the case. Therefore, an inflexible application of standardized procedures sometimes inay be unproductive and unduly burdensome. ${ }^{32}$ The drafters of the Local Rules of the Northern District of California recognized the need for flexibility and allowed judicial discretion to modify the standard pretrial procedure according to the simplicity or complexity of the case. ${ }^{33}$

In the Northern District of California, the parties can also request exeinption from any of the pretrial procedures that they believe will not be productive. Because of this provision, our rules can function at any point along the spectrum of complexity from "minimal" througli "intermediate" to "complex." Moreover, since the decision whether to modify the pretrial procedures for a given case will be inade after discussion of the question at a status conference, ${ }^{34}$ the judge's discretion will be informed by the parties' opinions and their faniliarity with the case. $^{35}$ Perhaps the difference between the Northern District's rules

of their strategies. A concise witness list, lowever, like most of the other requirements of our pretrial order, requires nothing that a respectable litigator, preparing for trial, would not do in any case. Moreover, the pretrial rules rarely force disclosures that will not already have been made in discovery. I have found the requirement that prospective testimony be described to be an extremely useful one. Quite often, the description reveals that the evidence is merely cumulative, or is offered on a point that is not, in fact, in issue. Many hours of court time can thus be saved if judges carefully examine this part of the pretrial statements and the proposed pretrial orders.

32. See, e.g. , Pollack, supra note 8, at 478; Address of Judge Milton Pollack, Meeting of the Judicial Conference of the Eighth Circuit (1970), reprinted in 50 F.R.D. 449, 459-60 (1970); Remarks of Judge J. Skelly Wright, Proceedings of the Seminar on Practice and Procedure, Annual Meeting of the Judicial Conference of the Tenth Circuit (1960), reprinted in 28 F.R.D. 141, 143 (1960).

33. N.D. CAL. R. 235-3(g). See note 36 infra.

Thus, more or less detailed requirements may be imposed in an individual case, following the status conference. But this flexibility is explicitly a matter of case-by-case determination and does not imply that judges are authorized to create their own rigid standing orders. In districts where the local rules do not specify pretrial procedures, judges often individually promulgate such standing orders. But this disuniformity of procedure is inconsistent with the spirit of the Northern District's Rule 235-7, whicl provides that the standard requirements for pretrial procedures set out in the local rules are to govern "except as may be otherwise provided by the status conference order . . . or by stipulation of the parties approved by the assigned judge."

34. See N.D. CAL. R. 235-3(g). At the status conference, the parties are expected to be prepared to discuss, among other matters, the necessity for further pretrial proceedings.

35. In this and several other respects, the Northern District of California's rule is consistent with the recommendations of the Federal Courts Committee of the Board of Governors of the State Bar of Califorma. See generally State Bar of California, Federal Courts Committee, Committee Report on Uniform Local Rules for the United States District Courts of the Ninth Circuit 122-31 (July 22, 1980). 
and other, less stringent rules is one only of perspective: in the Northern District the assumption is that all but the simplest cases will benefit from complete pretrial procedures, while in soine other courts the assumption is that all but the most complex will not.

\section{B. Pretrial Proceedings in the Northern District of California}

As noted above, the Northern District's rule provides for two types of pretrial meetings. First, the status conference allows counsel and the judge to plan the activity that will occur before trial-most notably, discovery, pretrial motions, and the final, formal, pretrial conference. Second, in the pretrial conference the trial itself is plarmed and shaped.

\section{Planning the Activity that Will Occur Before Trial: The Status Conference}

Under our rule, ${ }^{36}$ the status conference is a flexible procedure, well suited for resolving certain logistical problems at an early stage in litigation. It is convened by order of the court or by a party's request for a status conference. Some judges have standing orders setting mandatory status conference dates sixty to ninety days after the coinmencement of a suit. The provision allowing attorneys to inove for status conferences is a valuable aspect of our local rules. Thus, even if a judge does not take the initiative to set the conference, a party who perceives a need to organize the pretrial schedule and commit his opponent to court-ordered deadlines can obtain assistance froin the court.

Our rule directs attorneys to coine prepared to discuss such proce-

36. N.D. CAL. R. 235-3 provides for the status conference:

At any time after an action or proceeding has been filed, the assigned judge may, with or without the written request of any party, order the holding of a status conference. All parties receiving notice of the status conference shall attend im person or by counsel and shall be prepared to discuss such subjects as may be specified in the order noticing the status conference and, in addition:

(a) Service of process on parties not yet served;

(b) Jurisdiction and venue;

(c) Anticipated motions;

(d) Anticipated or remaining discovery, including limitation on discovery;

(e) Further proceedings, including setting dates for discovery cutoff, pretrial and trial, and compliance with Local Rules 235-7, 235-9, and 235-10;

(f) Appropriateness of special procedures sucl as consolidation of actions for discovery or pretrial, reference to a master or inagistrate, to arbitration, or to the Judicial Panel on Multidistrict Litigation, or apphication of the Manual for Complex Litigation;

(g) Modification of the standard pretrial procedures specified by this Rule on account of the relative simplicity or complexity of the action or proceeding;

(h) Prospects for settlement;

(i) Any other matters which inay be conducive to the just, efficient and economical determination of the action or proceeding, including the definition or limitation of issues.

Continuances of status conferences shall be governed by Local Rule 220-11, unless otherwise ordered. Status conferences may from time to time be held in any actiou or proceeding as herem provided. 
dural questions as service of process, jurisdiction, venue, the timetable for remaining discovery and pretrial, and the appropriateness of consolidation, reference to a master, arbitration, and other special procedures. Attorneys are also required to be prepared to discuss prospects for settlement. Although this meetimg occurs promptly after the commencement of the suit, it concerns crucial procedural issues that all attorneys should confront at the outset of a case.

The status conference itself is usually quite informal. Perhaps I can best describe it by reference to my own experience. I generally arrange a telephone conference call, with a reporter present, rather than an actual meeting. First, I ask the parties to describe the nature of the case and to outline briefly their impressions of the legal and factual issues that are likely to be disputed. Delineation of the issues serves two purposes: it allows the discovery plan to be designed in the most efficient and least costly manner, and it helps to illuminate possible grounds for motions to dismiss and for summary judgment.

Next, we attempt to formulate a discovery plan. I ask the parties how inuch information can be exchanged informally, and whether they anticipate any inajor discovery disputes. If so, I urge the parties to meet and atteinpt to agree, but I also schedule a date for discovery motions that can be foreseen at this early time. After asking the parties for estimates of how many witnesses will have to be deposed and how much other discovery is necessary, I set a discovery cutoff date.

A central concern of discovery planning at the status conference, and one frequently overlooked, is to ininimize the expense of discovery. If the parties cannot be persuaded to cooperate with one another, this cost can drive many litigants out of court. Having the issues delineated beforehand helps minimize discovery costs, since the parties can then be steered away froin aimless or redundant discovery.

The informal outline of the issues at the outset of the status conference also helps the parties focus on possible grounds for dismissal or summary judgment. If it seems that such motions are probable, I set dates and briefing schedules for them at the status conference. This provides far inore notice of possible notions than would otherwise be provided under our local rules of motion practice, under which notice of notion must be given not less than twenty-eight days before the date set for liearing the motion. ${ }^{37}$ This practice assures ainple time for counsel to prepare their moving and opposing papers.

Finally, as noted above, the status conference provides an opportunity to modify the standard complex pretrial procedures to suit the

37. N.D. CAL. R. 220-2. 
needs of a particularly simple or complex case..$^{38}$

Although seldom articulated, standards for determining when to modify pretrial procedures have developed. Cases with multiple parties having divergent interests, multiple claims, complex factual issues, unsettled or complicated legal questions, or troubling evidentiary problems usually benefit from fairly elaborate pretrial. Indeed, if several of these factors are present, special management procedures, such as reference of discovery matters to a magistrate or master, should be considered. In addition, the judge should consider his sense of the attorneys' diligence, experience, and competence. Since a structured pretrial can force attorneys to prepare, even a simple case can benefit from elaborate pretrial where the attorneys might otherwise allow the case to fall into confusion. A judge sliould also be alert to the particularly combative attorney who, if the case is not actively managed during pretrial, miglit succeed $\mathrm{m}$ turning a trial that should be a molehill into a mountam.

Conversely, when the case is quite simple and the attorneys seem to have it under control and appear to be willing to resolve minor disputes on their own, many of the usual pretrial procedures would be a waste of paper, time, and money. If the anticipated length of trial is quite short, if there are few witnesses and little documentary evidence, and if there are very few disputed issues of law or fact, the status conference-at which pretrial motions, discovery, and the trial itself are scheduled-may be all that is needed for effective pretrial management. The pretrial conference, elaborate pretrial statements and orders, and early evidentiary rulings may be quite unnecessary. It might, however, be helpful to have the parties submit simple statements summarizing the evidence they intend to offer, or to have an informal pretrial meetimg at whicl proposed evidence can be discussed. Where the factual dispute is quite narrow, the parties may be inclined to offer cumulative evidence. The judge can poimt out cumulative evidence listed in the pretrial statement or discussed at the pretrial meeting, and thus help streamline even these simple cases. Since a competent attorney would probably prepare a similar list of evidence for his own use, requiring submission of the list at this stage should not be unduly burdensome.

I believe that the key to effective pretrial planning is judicial flexibility. A judge should always be open to modifying the plan should that become necessary. If judges are sensitive to the parties' needs and flexible if it turns out that the pretrial procedures are wasting more time

38. See N.D. Cal. R. 235-3(g). See also text accompanying notes 32-34 supra. 
than they save, the problem of over-regulation, which has so disturbed participants on both sides of the bench, can be avoided.

Because tailoring the subsequent pretrial procedures is such a valuable device to promote efficiency, I would strongly support amendment of Rule 16 to make deviation from standard pretrial procedures a mandatory subject of consideration at the status conference. This requirement would help avoid the problem of over-regulation of cases that has generated so much resistance to comprehensive pretrial procedures. ${ }^{39}$ Simce the status conference provides a forum at which each party may express his opinions and wishes, pretrial procedures will not have been shaped by fiat. In my experience, the parties are more cooperative during pretrial when they have participated in forming the process.

Although the primary functions of the status conference are to resolve scheduling matters, shape further pretrial procedures, and formulate a discovery plan that will be cost-efficient, certain intangible benefits also flow from this early meetimg of attorneys and judge. The meeting itself warns the attorneys that they have a vigilant judge, and it may therefore prod attorneys who might otherwise be less than dihigent into transferring the case to their "active" files. The conference can also give the judge a "feel" for the case and the attorneys. For exainple, he may pick up early signals that an attorney tends to be careless or to procrastmate, perhaps warranting a fairly rigid timetable and a warning that it will be strictly enforced. Or, he may see that the parties are particularly combative and thus likely to engage in many pretrial disputes. He inay glean that one or both attorneys are confused about important legal or other issues in the action, so that the later, formal pretrial conference and order should be comprehensive. In short, the status conference is usually the first personal contact between the judge and the attorneys, and the judge can use his considerable influence to set the tone of a relationship in which he and the attorueys are likely to be engaged for the duration of the hitigation.

I hope the foregoing discussion, based primarily on my personal observations and impressions, will help to dispel both the notion that strict scheduling represents an untutored devotion to efficiency in preference to justice or fairness, and the notion that in inost cases pretrial does not even further the end of efficiency. Many people, however, find statistics more persuasive than personal inipressions. Although it is obviously very difficult to quantify the force that a judge's own personality exerts on the pretrial proceedings he conducts, one study suggests that strict enforcement of pretrial timetables leads to greater efficiency without a sacrifice in quality.

39. See, e.g., notes 80-82 and accompanying text infra. 
In 1975, the Federal Judicial Center mobilized a group of researchers, known as the District Court Study Project Team, to conduct a study of the case management practices of six metropolitan district courts. ${ }^{40}$ The six courts that were studies varied in median disposition time from 121 days in the Southern District of Florida to 500 days in Massachusetts. ${ }^{41}$ The study explored the reasons for this disparity by examining the procedures in each district during the various stages of hitigation in the district courts, as well as the extent of judicial participation in the hitigation process. Not surprisingly, the primary finding of the report was that greater and earlier judicial control of civil cases yields faster rates of disposition of those cases: "We found that a court can handle its case load rapidly only if it takes the initiative to require lawyers to complete their work in a timely fashion." 42

The faster courts characteristically kept stricter control of the case by precise scheduling of the discovery cutoff date and other deadlines. ${ }^{43}$ Moreover, they tended to employ routine, automatic procedures to assure that answers were timely filed and that discovery began and ended promptly. ${ }^{44}$ Although the study found that in all cases considerable time elapsed between motions and other events moving a case to final disposition, these intervals were shorter for the courts exercising more supervision. ${ }^{45}$ Nor could the differences in disposition time among the courts studied be attributed to a concentration of coinplex cases in the slower courts. The slower courts disposed of each type of case more slowly than did the faster courts. ${ }^{46}$

These gams in efficiency did not necessarily imdicate sacrifices in quality. Despite the fact that in the faster courts cases spent less time on the dockets, the study found that the faster courts ruled on more motions per case than the slower courts. ${ }^{47}$ This finding suggests that the faster courts actually tended to provide more rather than less careful consideration of each case, and that the slower courts were slow largely because they permitted long periods of mactivity in the average case. In fact, the study expressly concluded that the slower courts could reasonably reduce the vast amount of wasted time through closer docket control by the court. ${ }^{48}$

40. Case Management Study, supra note 7, at 1,5. The six districts studied were the Southern District of Florida, the Central District of Cahifornia, the District of Maryland, the Eastern District of Louisiana, the Eastern District of Pennsylvania, and the District of Massachusetts.

41. Id. at 19. See also note 50 infra.

42. Case Management Study, supra note 7, at 17.

43. Id. at 19.

44. Id. at 20.

45. Id. at 19.

46. Id. at 18.

47. Id. at 19.

48. Id. 
The study also found that, although other variables were important, ${ }^{49}$ a key variable in efficient disposition of civil cases was the time interval between the answer to the origmal complaint and the date on which the first conference of court and counsel occurred. The range of intervals in the districts studied was extremely great and directly reflected the rate of disposition in general. ${ }^{50}$ This finding supports iny

49. In addition to a prompt pretrial conference, other factors were found to be vital to efficient case management:

Pleadings. The study found that "timely filing of the answer [was] a precondition to subsequent judicial case management." Id. at 21 . It concluded, however, that few answers are timely filed, despite the 21-day deadline provided in the Federal Rules of Civil Procedure. And surprisimgly, both Central California and Eastern Louisiana, with the longest delay between the filing of the complaint and the filing of the answer, employ rigorous systeins to enforce filing dates. The report lyypothesizes that the customary practice of the state bar in eacli of the districts has a great effect upon the filing of an answer. And although, substantial delays in serving process were found im a sizeable ininority of cases, the study concluded that, for the inost part, service delays were a small part of the problem of delayed answers. Id. at 21-23.

Discovery. The time from filing of the complaint to the initiation of discovery varied widely among the courts studied. Fastest was the Southern District of Florida, which showed a median of thirty-six days until the first recorded plaintiff discovery; the slowest was Massachusetts, where the median number of days between the filing of the complaint and the first recorded plaintiff discovery was 119 days. Id. at 26. Sinnilar disparities were found in the time elapsed froin filing of the coinplaint until substantial completion of discovery. And, imterestingly, the study showed that tight discovery control did not have an oppressive effect on the conduct of the discovery process. The district with the fastest discovery also had the inost discovery requests filed per case while the slowest district slowed the fewest discovery requests. Id. at 27 . The report also revealed that individual discovery responses are filed inore promptly in courts with strong controls, as are motions to compel and the coinpelled answers. $I d$.

Motions. As motion practice is diverse and not directly controlled by most docket management systems, the report concerned itself only with some general observations on the tiining and treatment of motion practice. The study pointed out that swift responses to inotions can significantly speed up the progress of litigation, as a pending motion may curtail work on the other aspects of the case. Id. at 30 .

The study did find that routine oral argument speeds disposition of substantive motions, although it also concluded that delay in ruling on motions was not a significant problem in any of the districts studied. Oral argument on inotions tends to speed the litigation in three ways: An automatic learing date based on the filing date of the inotion establishes a schedule for every motion; the judge has an early opportunity to discuss the possible ranifications of the proposed ruling with counsel, saving time later in the action; and "the oral proceeding provides a useful opportunity for a court to communicate its standards and expectations to the bar generally." Id. at 31 .

50. The study summarized the tiune intervals as follows:

\begin{tabular}{lccc} 
& \multicolumn{2}{c}{ Median Number of Days } \\
District & $\begin{array}{c}\text { Between Answer and Date on Which } \\
\text { First Pretrial Date is Set }\end{array}$ & $\begin{array}{c}\text { Total } \\
\text { Disposition }\end{array}$ \\
Southern District of Florida & 18 & 121 \\
Central District of Califorina & 21 & 166 \\
District of Maryland & 82 & 223 \\
Eastern District of Louisiana & 104 & 313 \\
Eastern District of Pennsylvania & 175 & 352 \\
District of Massachusetts & 595 & 500 \\
\hline
\end{tabular}


personal impression that a fairly prompt status conference date prods lawyers to prepare themselves and sets the tenor of the entire litigation, by making it clear at the outset that the judge will take an active interest in the management of his cases.

The status conference, then, can be extremely productive without being very burdensome to court or counsel. Therefore, I feel strongly that Rule 16 should be amended so that, like Rule 235-3 of the Northern District of California, it explicitly requires an early status conference. This would encourage the practice of establishing early judicial control of hitigation, a practice that is already widespread and that has proven to be extremely helpful.

Simce the status conference is most helpful when held promptly, Rule 16 should require it to be held within a specified time after the commencement of the action. I believe that sixty to ninety days provides ample time for the parties to prepare themselves to schedule their pretrial activity, and this belief seems to be justified by experience im the Northern District of California.

\section{Planning the Trial: The Final Pretrial Conference}

The better-known type of pretrial meetimg, usually denominated the "pretrial conference," represents the second phase of pretrial. During this conference the trial itself is planned. This meeting is more formal than the status conference, it requires more paperwork of the attorneys, and it seems to be the phase that the bar finds most objectionable. While this phase is imdisputably not as productive in proportion to the amount of preparation required as is the status conference, I beheve that it also is an essential tool for case management. If pretrial rules are not too rigidly applied in cases where there is little need for comprehensive pretrial, this second phase can easily save litigants and the court time and money.

The date for the pretrial conference can be set in three different ways: at the status conference, by standing order, or by an order made

Case Management Study, supra note 7, at 19, 35. For discussion of the "Total Disposition" scores, see text accompanying notes 35-36 supra. Note that figures for Massachusetts appear confusing since the median disposition time, 500 days, is shorter than the median time between the answer and the date on which the first pretrial date is set. The reason for this is that many cases reach disposition-through settlement, pretrial motions, or dismissal-long before any pretrial date is set. Judges $m$ the District of Massachusetts wait so long before setting the pretrial date that many cases have already run their course. 
at the request of a party. ${ }^{51}$ Most judges prefer to hold the pretrial conference a few weeks before trial, when discovery has ended or nearly ended. ${ }^{52}$ By this time the lawyers typically will have gathered their evidence and familiarized themselves with the issues, yet there is still an opportunity to avert serious mistakes. On a date soon before trial, the attorneys are more likely to be impressed with the seriousness of the conference and to give it their best efforts.

In extremely complex cases many judges hold a series of conferences, beginning with the status conference and culminating with a final pretrial conference on the evening of the trial. Complex cases can also soinetimes benefit from increased formality, which, though it may require some sacrifice of the spirit of cooperation generated by informal meetings, seems to help the attorneys focus on the issues.

Since the purposes of the final pretrial conference are defeated when the attorneys are not sufficiently informed to describe their proposed evidence or enter into stipulations, our rules require extensive preparation by the attorneys. ${ }^{53}$ Counsel are directed to meet at least twenty days before the conference to discuss preparation of a joint pretrial statement or coordination of separate statements if agreement on a joint statement cannot be reached. ${ }^{54}$ These statements must be submitted at least ten days before the conference. ${ }^{55}$

At the conference, I expect to see the attorneys who will be trying the case should it go to trial. Counsel should come armed with authority to negotiate and compromise, bringing their clients to the conference if necessary. It is unfair to the other parties, and wasteful of the court's time, when an attorney attends a pretrial conference without detailed knowledge about the case or without the authority to make binding stipulations and compromises.

The pretrial conference agenda depends entirely on the nature of the litigation. ${ }^{56}$ I try to take the imitiative in urging the parties to agree on at least some issues. Although judges vary in the degree to which they will actively atteinpt to urge agreements by the parties, no agreement is possible if the parties take rigid stands and fail to act in a spirit

51. N.D. CAL. R. 235-5.

52. In the Handbook for Effective Pretrial Procedure, 37 F.R.D. 255, 269 (1964), the Judicial Conference of the United States recommended holding the conference at "a date between one and three weeks prior to trial and after the completion of discovery."

53. See N.D. CAL. R. 235-7, quoted at note 30 supra.

54. N.D. CAL. R. 235-6. This mandatory pretrial meeting is recommended in the Handbook for Effective Pretrial Procedure, supra note 52, at 265.

55. N.D. CAL. R. 235-7.

56. It will have been planned in advance at the status conference, according to the complexity of the case and the perceived needs of the parties. See notes 38-39 and accompanymg text supra. 
of reciprocity. Generally, however, the issues can be meaningfully limited and defined in a relatively short period of time.

The pretrial conference usually results in the entry of a pretrial order. ${ }^{57}$ Generally, the plaimtiff subımts a proposed pretrial order as a working draft. The final order will memorialize the results of the conference.

I regard the pretrial order as fully binding on the parties. If an attorney can show that he entered into an agreement or waiver by honest mistake, and that there will be no possible prejudice to the other side, I may allow deviations from the pretrial order, but generally I believe that strict enforcennent of pretrial orders is essential to maintaining effective pretrial procedures. ${ }^{58}$ If pretrial orders are not strictly enforced, their purposes are often frustrated: orders that are not enforced will usually have wasted rather than saved time and expense.

In most instances the pretrial order is quite brief, ${ }^{59}$ perliaps because of the bar's resistance to complex, comprehensive, and burdensome pretrial orders. Many attorneys feel that such orders are, im effect, analogous to the much-maligned code and common law pleadmg systems that once prevailed in this country, and are therefore contrary to the spirit of simplicity embodied in the Federal Rules of Civil Procedure. ${ }^{60}$ Some members of the bar also feel that many judges use burdensome pretrial rules as a wedge for settlement and that such rules have little to do with simplification of the issues for trial. ${ }^{61}$

In simple cases, a compreliensive pretrial order may not be necessary. However, in appropriate cases-namely, those in which the evidence is likely to be voluminous, the theories circuitous, and the litigation protracted-a comprehensive order is helpful, precisely because it can serve the very functions to which the bar so strenuously objects. As couninon law pleading should have done, a comprehensive order apprises the court and the parties of the shape of the evidence. I do not unind saymg that, in a trial lasting several weeks and involving complex transactions taking place over years or decades, I appreciate any evidentiary signposts erected in the pretrial order. I like knowing in advance the reason for offering an item of evidence. We must simply trust most judges to respond sensitively and not to engage in the hypertechnical enforcement that caused most of the problems with common law pleading. The current climate, which generated "notice

57. Pretrial orders are authorized by FeD. R. CIV. P. 16 and by N.D. CAL. R. 235-9.

58. See notes 92-104 and accompanying text infra.

59. Case Management Study, supra note 7, at 39.

60. Friedenthal, A Divided Supreme Court Adopts Discovery Amendments to the Federal Rules of Civil Procedure, 69 Calif. L. Rev. 806, 815 (1981).

61. See, e.g., Kahn, Local Pretrial Procedures Rules in the Federal Courts, 6 LITIGation, No. 3 , at 34 (1980). I have frequently heard these views expressed at Bar Association meetings. 
pleading" and the Federal Rules of Civil Procedure, favors flexibility and discourages semantic gamesmanship. Common law pleading, and its occasional injustices, was a product of an entirely different climate in the legal community-a climate which encouraged formalism, often at the expense of justice. Lawyers should not, therefore, assume that the harsh experience of code and common law pleading will recur if comprehensive pretrial orders are considered to control subsequent litigation.

Additionally, while a comprehensive order can help to promote settlement, it may do so in legitimate or in illegitimate ways. If some judges use pretrial procedures simply to overwhelm attorneys with busywork in order to browbeat them into settlement, then the bar's distaste for elaborate procedures is understandable. In iny experience, however, requiring the attorneys to prepare a comprehensive pretrial stateinent and order proinotes settlement primarily because these pretrial tasks illuminate the strengths and weaknesses of each side's case. Comprehensive procedures also force the attorneys-perhaps for the first time-into a graphic confrontation with the probable cost of trial, obviously an important factor in the settlement process. If these are the reasons that a comprehensive pretrial process promotes settleınent, then the bar should not coinplain.

The Judicial Center's Report concluded by prescribing "an expeditious schedule, firmly and reahistically enforced, leading to a pretrial order tailored to the needs of the case"62 in order to achieve effective case management in the federal district courts. I concur wholeheartedly in this prudent suggestion.

This discussion of the impact of pretrial on settlements suggests another potential modification to Rule 16 of the Federal Rules of Civil Procedure. The rule should forthrightly acknowledge settlement promotion as a legitimate function of pretrial procedure. Although pretrial procedures effectively promote settleinent by requirmg parties to prepare, to examme the strengths and weaknesses of their case, and to confront the possible expense of trial, some judges may feel reluctant to urge the parties to consider settlement possibilities as new aspects of cases emerge durmg pretrial. If Rule 16 provided explicit authority to do so, this reluctance might be overcoine.

A judge should, of course, be wary of appearing to coerce settlement, either by using overly burdensoine pretrial procedures as a bludgeon or by becoming overly involved in the settleinent process. But Rule 16 should nnake it clear that the possibility of settleinent is a permissible subject of consideration at all pretrial meetimgs. It should

62. Case Management Study, supra note 7, at 40. 
also make it clear that, while one purpose of obtaining stipulations and rulings is to streamline the case for trial, counsel should constantly reexamine the possibility of settlement in light of these pretrial determinations.

In order to allay fears about judicial involvement in the settlement process, the rule might also provide that reference of settlement discussions to a magistrate or another judge may also be discussed at pretrial conferences. Agaim, this amendment would do no more than bring Rule 16 into harmony with an existing, salutary practice.

After the pretrial conference, the Northern District's local rules require the parties to submit briefs on "all significant disputed issues of law, imcluding foreseeable procedural and evidentiary issues." 63 The parties must also provide the court with proposed voir dire questions, jury instructions, and forms of verdict in jury cases. ${ }^{64}$ In judge-tried cases, attorneys must prepare proposed findings of fact and conclusions of law. ${ }^{65}$ To simplify evidentiary questions, our rules require parties to exchange copies of all exhibits and to specify all excerpts from depositions that they propose to use as direct evidence. ${ }^{66}$ All of this activity must take place at least a week before the scheduled trial date, ${ }^{67}$ and some judges and trial counsel prefer the briefs to be exchanged earlier.

After the proposed documentary evidence has been exchanged, the parties are directed to inform each other about any objections and to confer im an attempt to resolve them. ${ }^{68}$ If the parties cannot agree, they must inform the trial judge of their objections and make reasonable efforts to present them for an early ruling. ${ }^{69}$ This procedure allows the judge to dispose of many evidentiary questions without time-consuming and distracting disputes during the actual trial. In some cases, sigmificant evidentary rulings can lead the parties to settle the action. It is obviously sound practice to make sure such rulings are made as early as possible.

\section{II}

\section{Enforcement of Pretrial Rules}

If pretrial rules are to be respected, there must be effective incentives to ensure coinpliance. Two primary sanctions for violations of pretrial orders have developed: first, dismissal of the plaintiff's action

\footnotetext{
63. N.D. CAL. R. 235-9(a).

64. N.D. CAL. R. 235-9(b)(i).

65. N.D. CAL. R. 235-9(b)(ii).

66. N.D. CAL. R. 235-9(c) and (d).

67. N.D. CAL. R. 235-9.

68. N.D. CAL. R. 235-10.

69. Id.
} 
for failure to prosecute, or default when the defendant is the violator, and second, imposition of fines or taxing of costs caused by the disobedience. Compliance, however, should not be pursued for its own sake but, rather, because noncompliance will usually prejudice the opposing party. In cases where this is not true, or where justice seems to require some flexibility, a judge should consider whether to condone deviations from the pretrial order. The determination whether and how to enforce the pretrial order generally rests in the trial judge's discretion, so I will first briefiy review appellate treatment of that discretion.

\section{A. The Limits of Appellate Review of District Court Rulings}

Although many lawyers have long regarded pretrial procedures as time-wasting, bothersome, and arbitrary, they have rarely appealed the imposition of sanctions for violations of pretrial rules. Three reasons have been suggested for the sparsity of case law in this area. First, lawyers are reluctant to jeopardize their reputations and their relationship with the local judges by advertising their disagreements with a particular judge. Second, most sanctions are fairly minor except in cases of truly outrageous behavior-and in those cases an appeal would be professionally embarrassing. Third, and most important, until very recently most appellate courts held the view that district courts had virtually unfettered discretion to enact and enforce pretrial rules, regulations, and procedures, and considered that this discretion was supported by broad sanctioning powers. ${ }^{70}$

The Supreme Court's opinion in Link v. Wabash Railroad Company $y^{71}$ initially set the tone for the extremely deferential attitude of the appellate courts toward the district courts' authority to use pretrial procedures to "achieve the orderly and expeditious disposition of cases."72 In Link the Supreme Court affirmed the district court's sua sponte dismissal of the plaintiff's complaimt with prejudice, for failure of plaintiff's counsel to appear at a pretrial conference the court had ordered pursuant to its local rules. Plaintiff's attorney had telephoned the court on the morning of the conference, and left a message with the judge that he would be unable to attend because he was preparing papers to be filed in the Indiana State Supreme Court. Two hours after the appointed hour for the conference, the district court, exercised what it termed its "inherent power," prosecute. A divided court of appeals affirmed, as did the Supreine Court, despite Justice Black's fear that "this case is not likely to stand

70. Kahn, supra note 61 , at 35-36.

71. 370 U.S. 626 (1962).

72. Id. at 631.

73. Id. at 629 . 
out in the future as the best example of American justice."74

In Link, the Supreme Court affirmed that a district court has inherent power to dismiss cases on its own motion for failure to prosecute, a power that had never seriously been questioned and that was already widely exercised. But it also emphasized the broad discretion a court has in entering such dismissals. Justice Black, dissenting, insisted that "the most fundamental ideas of fairness and justice" demand some form of notice to the chent before the sins of his attorney are so drastically visited upon him. ${ }^{75}$ Justice Black also imsisted that the "very laudable objective" of reducing congested court dockets "should not be sought in a way which undercuts the very purposes for which courts are created-that is, to try cases on their merits and render judgments in accordance with the substantial rights of the parties."76 In any case, he doubted that the objective of increasing judicial efficiency could be achieved by dismissing meritorious cases, because litigants with strong cases would not accept such dismissals without exhausting all available appellate remedies ${ }^{77}$-as, indeed, Link himself had done.

Even Justice Black, however, did not dispute that a trial court had the power to impose heavy sanctions for failure to follow its procedural rules. In his opmion, a court did have power to impose fines, to treat issues as waived, and perhaps even to dismiss in exceptional cases when the client himself has participated in the breach. Hence, the Link Court and its dissenters disagreed primarily about the scope of appellate courts' power to limit district courts' discretion, particularly when the exercise of that discretion results in such drastic action as dismissal.

The dismissal of Link's action seems too severe a response to the attorney's conduct. Justice Black's extensive review of the facts strongly suggests that relegatimg Link-who had suffered serious personal injuries-to a malpractice action against his attorney was indeed a serious injustice. My theoretical sympathies, however, lie with the Court: although as a judge I would rarely invoke the drastic sanction of dismissal, I believe that, except in cases of gross abuse, pretrial con-

74. Id. at 649.

75. Id. at 643. Justice Black convincingly described the client's plight:

How could [the client] know, even assuming that it is true, that his lawyer was a careless man or that he would have an adverse effect upon the trial judge by failing to appear wheu ordered? How could he know or why should lie be presumed to know that it was his duty to see that the many steps a lawyer needs to take to bring his case to trial had been taken by his lawyer? Why should a clieut be awakeued to his lawyer's incapacity for the first time by a sudden brutal pronounceinent of the court: "Your lawyer has failed to perform his duty im prosecuting your case and we are therefore throwing you out of court on your heels?"

Id. at 647-48.

76. Id. at 648 .

77. Id. at 649. 
trol must be left in the hands of trial judges, who must be free both to relax and to enforce their pretrial rules.

Link was followed by numerous appellate decisions vindicating the district court's power to shape and enforce pretrial procedures. The Fifth Circuit's pronouncement in Davis v. Duplantis, ${ }^{78}$ where the trial court had permitted a witness to testify even though the witness was not listed as a prospective witness im the pretrial order, is typical:

Rule 16 of the Federal Rules of Civil Procedure, permitting pretrial procedures, can achieve its purpose of improving the quality of justice only if the pretrial requirements entered at the discretion of the trial court are applied with intelligent flexibility, taking into full consideration the exigencies of each situation. The trial judge must be permitted wide latitude in guiding a case through its preparatory stages. His decision as to the extent that pretrial activity slould prevent the introduction of otherwise competent and relevant testimony at trial must not he disturbed unless it is demonstrated that he has clearly abused the broad discretion vested in him by Rule $16^{79}$

In $M c$ Cargo v. Hendrick, ${ }^{80}$ lowever, the Fourtli Circuit abruptly abandoned this traditional "hands-off" attitude. In this remarkable case, the court struck down, in its entirety, the local pretrial rule of the Northern District of West Virginia. The local rule, at first glance, seemed quite innocuous; it required that opposing counsel "confer and . . . meaningfully and effectively express and commit themselves in a written statement on matters and issues involved in controlling determination of the action." 81 However, this first sentence of the rule was falsely reassuring. Numerous, imfinitesimally detailed "implementation" provisions, administered by a rather finicky magistrate who ordered even more specific ainendments to plaimtiff's proposed pretrial order, ultimately made it impossible for plaimtiffs to comply with the rule. When plaintiffs failed to file a third amended proposed pretrial

78. 448 F.2d 918 (1971). See also Flaska v. Little River Marine Constr. Co., 389 F.2d 885, 885-88 (5th Cir.), cert. denied, 392 U.S. 928 (1968); Torino v. Texaco, Inc., 378 F.2d 268, 270 (3d Cir. 1967); Grunewald v. Missouri Pac. R.R., 331 F.2d 983, 985-86 (8th Cir. 1964); Esteva v. House of Seagram, Inc., 314 F.2d 827, 829-30 (7th Cir.), cert. denied, 375 U.S. 826 (1963). Interestingly, the attorney in Esteva was the same attorney whose delinquency motivated the dismissal in Link. See 314 F.2d at 829.

79. 448 F.2d at 921 . See Transamerica Corp. v. Transamerica Bancgrowth Corp., 627 F.2d 963, 966 (9th Cir. 1980); McGrady v. D'Andrea Elec., Inc., 434 F.2d 1000, 1001 (5th Cir. 1970). But see Dove v. CODESCO, 569 F.2d 807, 810 (4th Cir. 1978); Beshear v. Weinzapfel, 474 F.2d 127, 131 (7th Cir. 1973); Fischer v. Buehl, 450 F.2d 950, 951 (3d Cir. 1971); Delta Theaters, Inc. v. Paramount Pictures, Inc., 398 F.2d 323, 324 (5th Cir.), cert. denied, 393 U.S. 1050 (1968); Durham v. Florida E.Coast Ry., 385 F.2d 366, 368 (5th Cir. 1967), suggesting that the drastic sanction of dismissal should be invoked only when there is deliberate delay or a pattern of uncooperative conduct.

80. 545 F.2d 393 (4th Cir. 1976).

81. Id. at 394 . 
order on time because, they claimed, defendants had failed to produce their hists of documentary evidence, the court dismissed the case sua sponte with prejudice. The Fourth Circuit, insisting that "local rules are not a source of power but are instead a inanifestation of it," held the local rule "void and of no effect," as being inconsistent with Rule $16^{82}$

The McCargo court's analysis closely resembled the analysis in Padovani v. Bruchhausen, ${ }^{83}$ a pre-Link case that had also invahdated certain local rules as mconsistent with Rule 16. Decided one year before Link's affirmation of the district court's rulemaking power, Padovani was largely ignored by district judges. The period following Padovani was marked by a proliferation of pretrial rules and standimg orders arguably violating its mandate. Some litigators hope that $\mathrm{MC}$ Cargo will not suffer the saine fate as Padovani. ${ }^{84}$ Unlike Padovani, they note, $M c C a r g o$ has not been closely followed by a contrary pronouncement by the Supreme Court. In fact, simce $M c$ Cargo was decided three circuits have reversed district court rulings sanctioning parties for their lawyers' failure to comply with local rules of pretrial and discovery. ${ }^{85}$ Thus, some litigators hope that $M c$ Cargo will induce other circuits to curb the trial courts' virtually unfettered discretion to impose sanctions.

Silas v. Sears, Roebuck and Co. ${ }^{86}$ seems to express the new mood after McCargo. In Silas, plaintiff's counsel violated the local rules in several respects: he failed to respond to soine of defendant's imterrogatories, he failed to meet with opposing counsel before the pretrial conference to mark out areas of agreement, and he failed to appear at the pretrial conference. At the conference the judge granted the defendant's oral motion for dismissal. Plaintiffs subsequent motion, seeking rehef from the order of dismissal on the ground of "excusable ne-

82. Id. at 402 .

The court described the local rule as follows:

The theory seems to be that if two pages are good, four must be better, and ten or thirteen or twenty-one may prevent a trial altogether, as happened here . . . [The local rule] is inquisitorial in tone and purpose. [It] subordimates the role of the lawyer to that of the administering magistrate, reducing counsel to the role of clerical assistants who are to anticipate imaginatively what ... matters ought to be embraced within an endless pretrial order.

Id. at 401 .

83. 293 F.2d 546 (2d Cir. 1961).

84. See Kahn, supra note 61 , at 62.

85. See Silas v. Sears, Roebuck \& Co., 586 F.2d 382 (5th Cir. 1978); Identiseal Corp. v. Positive Identification Sys., Inc., 560 F.2d 298 (7th Cir. 1977); Edgar v. Slaughter, 548 F.2d 770 (8th Cir. 1977). But see Transamerica Corp. v. Transamerica Bancgrowth Corp., 627 F.2d 963, 966 (9th Cir. 1980); McGrady v. D'Andrea Elec., Inc., 434 F.2d 1000, 1001 (5th Cir. 1970); Flaska v. Little River Marine Constr. Co., 389 F.2d 885, 885-88 (5th Cir.), cert. denied, 392 U.S. 928 (1968).

86. 568 F.2d 382 (5th Cir. 1978). 
glect,"87 was denied.

The Fifth Circuit, however, did not defer to the trial judge's discretion. In reversing the district court's rulings, the court first acknowledged the teachings of Link, stating that "[t]] withstand appellate reversal, the choice of a particular sanction in a given case need merely fall within the permissible range of the court's discretion in light of the circumstances." ${ }^{88}$ The court added, however, that the discretion vested in the trial court to select an appropriate sanction is "not unlimited"89:

[D]ismissal with prejudice is a drastic remedy to which a court may resort only in extreme situations where there is a "clear record of delay or contumacious conduct by the plaintiff." . . . Dismissal is generally inappropriate and lesser sanctions are favored where neglect is plainly attributable to an attorney rather than to his blameless chient. ${ }^{90}$

Silas, unlike McCargo, did not invalidate the underlying local rules but only took a restrictive view of trial judges' discretion to enforce them. To the extent that McCargo invahidated a whole system of local rules, I regard it as an aberration, an expression of distaste as inuch for the draconian sanction of dismissal as for overly complex pretrial procedures themselves.

Although Silas and McCargo involved only the ultimate sanction of dismissal, soine may read thein as signalling a new nood of appellate activisin regarding all sanctions for the violation of pretrial rules.91 I do not believe that Silas, McCargo, and the other cases that have reversed orders of dismissal in this context have so broad a sweep. Trial court discretion with respect to the lesser sanctions that can be invoked in order to enforce pretrial rules seems to have reinained relatively undisturbed. These sanctions include the taxing of costs, imposition of fines, and preclusion of evidence. All are problematic to some degree, however, because, like the sanction of dismissal, they visit the sins of the attorney upon the chent's head. But our system of legal representation posits that people consent to be bound by most acts of their attorneys and assune the risk of most of their attorneys' mistakes. The

87. See Fed. R. Civ. P. 60(b)(1).

88. 586 F.2d at 385 .

89. Id.

90. Id. (citations omitted).

91. In this regard, it is notable that Silas arose in a context in which appellate courts have traditionally been doubly deferential: Not only did it concern pretrial procedures, an area traditioually left to the "unfettered discretion" of trial judges, but Silas was also an appeal of the denial of a Rule 60(b) motion (relief from a final judgment or order for mistake, inadvertance, fraud, etc.). As the Silas court acknowledged, "[the] authorities indicate that appellate review of the demal of a 60(b) motion unust be narrower in scope than review of the underlying order of dismissal," since any other rule would vitiate the shorter time limit for the filing of an appeal. $I d$. at 386 . Thus, the Silas court had two good reasons to defer to the district court's judgment of dismissal, and the fact that it did not do so indicates a strong distaste for dismissal as a sanction. 
McCargo and Silas courts may have viewed dismissal as outside the scope of any reasonably assumed risk. However, our adversary trial system would be paralyzed if judges could not enforce procedural rules and call litigants to account for their attorneys' mistakes, and the appellate decisions do not negate this power or remove it generally from trial court discretion.

Far short of dismissal, the sanction of precluding evidence not mentioned in pretrial is often imposed to avoid prejudice to opposing parties. This sanction is autliorized by Rule 16, but it is clearly discretionary. A judge may feel that deviation from a pretrial rule or order will not cause the court or the opposing party great imconvenience, and so decide not to preclude evidence. The next section discusses the standards that should govern the decision whether to preclude evidence for noncompliance with pretrial requirements.

\section{B. Preclusion of Evidence for Deviations from the Pretrial Order and Rules}

In some cases an attorney may have neglected to include some documents, evidence, or witnesses in a pretrial order. Or, he inay have neglected to include important legal or factual issues that he later wishes to address at trial. Circumstances may have changed, making new evidence available that could not have been included in the pretrial order. In all such cases the judge must decide whether to allow the party to deviate from the pretrial order and introduce the evidence at trial. Judges differ considerably in how firmly they hold the parties to the pretrial order. Some judges permit deviation quite freely, to avoid forcing a party to bear the brunt of his attorney's mistake. Other judges rarely, if ever, allow deviation from the order.

Two considerations mark the context for decisions about enforcing compliance with pretrial orders. The first is the fact that formal pretrial orders, which limit the issues and evidence pursuant to the parties' stipulations, are largely self-enforcing. Rule 16 states that the pretrial order "controls the subsequent course of the action, unless inodified at trial to prevent manifest injustice." Trial courts are presumptively justified in excludimg any evidence or argument concerning issues that are foreclosed by the pretrial order. ${ }^{92}$ And evidence may be excluded if not disclosed in accordance with a pretrial order..$^{93}$

The second consideration that frames decisionmaking about deviations from the pretrial order is the recognition that the trial judge's power to enforce the pretrial order is acconipanied by a power to waive

92. See 3 Moore's Federal Practice fl 16.19 (2d ed. 1980); 6 C. Wright \& A. Miller, Federal Practice and Procedure § 1527 (1971).

93. See, e.g., Burdis v. Texas \& Pac. Ry., 569 F.2d 320, 323 (5th Cir. 1978). 
or amend the order where justice so requires. Appellate courts have recognized that trial courts should have broad discretion to modify their orders. ${ }^{94}$ Thus, the question presented to the trial judge is not how to enforce the order, but rather whether the pretrial order should be relaxed in a particular circumstance.

Judges have been given very little guidance in exercising their discretion to allow deviation from pretrial rules and orders. The "manifest injustice" standard in Rule 16 is not very illuminating and has engendered varying interpretations. The Rule 16 standard properly suggests, however, that courts should be extremely reluctant to permit deviation froin the order. The philosophy underlying the rule is, in part, that "surprise, both as a weapon of attack and defense, is not to be tolerated." 95 Surprise may skew the results of litigation, and it has nothing to do witl the inerits of claims and defenses. Consequently, the parties should rarely be allowed to deviate at trial from the issues enumerated in the pretrial order, nor should they be permitted to offer documents, exhibits, or witnesses not identified at pretrial, ${ }^{96}$ except for impeachment purposes. If pretrial orders are too easily inodified at trial, there is no poimt in entermg thein at all, and practicing attorneys can rightfully complain that pretrial procedures are nothing but meaningless and expensive paper chases. Most courts have therefore insisted that the burden of establishing "manifest injustice" such as to warrant modifying the pretrial order falls on the noving party. ${ }^{97}$

The decision to relax the requirements of the pretrial order has generally been intuitive, and a judge may not always articulate with great precision the factors that have influenced him. ${ }^{98}$ I believe, however, that primcipled guidelines are necessary to provide judges with the basis for a more thoughtful deeision, to give parties and counsel an assurance of fair consideration, and to avoid the occasional reversal in the post-McCargo appellate chmate. The following discussion will

94. See, e.g., James v. Newspaper Agency Corp., 591 F.2d 579, 583 (10th Cir. 1979); Admiral Theatre Corp. v. Douglas Theatre Co., 585 F.2d 877, 898 (8th Cir. 1978); Davis v. Duplantis, 448 F.2d 918, 921 (5th Cir. 1971); Clark v. Pennsylvania R.R., 328 F.2d 591, 593-94 (2d Cir. 1964). But see Weiss v. Chrysler Motors Corp., 515 F.2d 449, 457-58 (2d Cir. 1975), in which the court held it an abuse of discretion to deny plaimtiff the opportunity to call an expert witness not listed in the pretrial order, to rebut the surprise testimony of defendant's expert, where the substance of the defense expert's testimony was within the scope of an interrogatory that defendant had failcd to answer truthfully and completely. Local Rule 235-7(i) of the Northom District of California specifically provides that potential rebuttal witnesses need not be histed in the pretrial order.

95. See Burton v. Weyerhaeuser Timber Co., 1 F.R.D. 571,573 (D. Or. 1941).

96. See Leach v. Chesapeake \& Ohio Ry., 35 F.R.D. 9, 11 (W.D. Mich. 1964).

97. See, e.g., Seneca Nursing Hoine v. Secretary of Social \& Rehab. Servs., 604 F.2d 1309, 1314 (10th Cir. 1979).

98. Smith v. Ford Motor Co., 626 F.2d 784 (10th Cir. 1980); Meyers v. Pennypack Woods Home Ownership Ass'n, 559 F.2d 894 (3d Cir. 1977). 
suggest some criteria that trial judges can use in the exercise of their discretion.

The judge's decision whether to insist on strict compliance with the pretrial order, by precluding issues and evidence not histed in accordance with a local rule, requires him to balance the likelihood that an unmerited penalty will be imposed on an innocent party against the need to prevent unfair surprise, delay, and inefficiency. In striking this balance the court should first consider the value of the evidence now offered for proof. The new evidence should have a substantial impact on the offering party's case. Merely repetitive or cumulative evidence should not seriously be considered.

The court should next consider prejudice or surprise to the party agamst whom the evidence is offered. Where a previously identified witness seeks to testify as to factual issues not listed in the pretrial statement, a key question in determining the likelihood of prejudice is whether the offered testimony represents a sharp deviation from the theories of the facts that the proponent has thus far propounded. This is also generally an important question when unlisted documentary evidence is offered at trial. If the new evidence seeks to explore new theories, the opposing party will probably be unprepared to counter the new evidence. Proper rebuttal will require extensive preparation. If, however, the deviation from the original theories is shght, then both the prejudice and the surprise sliould be minimal. The opposing party should already have gathered, or can now readily gather, witnesses and evidence to rebut the new evidence.

When an entirely new lay witness is called at trial, the likelihood of prejudice is generally quite high. However, if this new witness' testimony is only corroborative, any prejudice can probably be minimized by allowing the opponent to depose the new witness. If the witness seeks to testify as to new factual issues, however, the possibility of prejudice is even greater than in the situation just discussed, where a previously known witness adopts a new factual theory.

Special problems exist wlien the new evidence is the testimony of an expert witness not named in the pretrial order. In these instances deviation from the order should even more rarely be allowed. Rule 26 of the Federal Rules of Civil Procedure gives each party the right to discover the gist of his opponent's expert testimony through interrogatories. Federal Rules of Evidence 703 and 705 eliminate certain foundational requirements for expert testimony that were required at common law, and "place the full burden of exploration of the facts and assumptions underlying the testimony of an expert witness squarely on 
the shoulders of opposing counsel's cross-exammation." 99 Hence, im the case of expert witnesses it is especially true that effective cross-examination requires advance notice and preparation. ${ }^{100}$

The drafters of Rule 26, recognizing this special need for effective pretrial notice and preparation, provided that identification of experts is one of only three situations where a party must seasonably supplement his responses to requests for discovery. ${ }^{101}$ If that party finds new experts whom he imtends to call, or if the scope of a previously identified expert's expected testimony changes significantly, the party employing the expert has a duty to keep his opponent informed. ${ }^{102}$

The appellate courts have also tacitly recognized that allowing previously unidentified experts to testify presents special probleins. Despite their usually deferential attitude toward trial court decisions regarding deviation from pretrial orders, ${ }^{103}$ the appellate courts have frequently found reversible error in allowing the testimony of new experts. ${ }^{104}$

The need to call previously unidentified experts as often results froin a party's mistaken tactical decisions or froln a desire to save expert witness fees, as from the discovery of important new evidence. Moreover, allowing such experts to testify would nearly always require the reopening of discovery and significant disruption of the case. Therefore, unless the proponent can demonstrate good cause for his delay in identifying the expert and the "manifest injustice" that will result froin the expert's exclusion, experts not named in the pretrial order should not be allowed to testify.

Once the degree of prejudice is assessed, the judge should consider the ability of the offended party or the court to cure the prejudice. If there is httle prejudice, hitle, if anything, nay be required to cure it. If,

99. Graham, Discovery of Experts Under Rule 26(b)(4) of the Federal Rules of Civil Procedure: Part One, An Analytical Study, 1976 U. ILL. L.F. 895, 897.

100. See Fed. R. Crv. P. 26(b)(4), Comment (Advisory Committee Note on 1970 Amendments).

101. A party must also supplement responses concerning "the identity and location of persons having knowledge of discoverable matters." FED. R. C1v. P. 26(e)(1)(A). In addition, a party must also amend prior responses if he obtains new information which indicates that his prior response was incorrect when originally made, or when he knows that his originally correct response is no longer accurate and that failure to amend the response would constitute a knowing concealmeut. FED. R. CIV. P. 26(e)(2). Supplements to responses can be required "by order of the court, agreement of the parties, or at any time prior to trial through new requests for supplementation of prior responses." FED. R. CIV. P. 26(e)(3).

102. FED. R. CIV. P. 26(e)(1)(B). The rule requires disclosure of the subject matter of the witness' testimony as well as of the substance of the testimony.

103. See note 94 and accompanying text supra.

104. See, e.g., Shelak v. White Motor Co:, 581 F.2d 1155, 1159-60 (5th Cir. 1978); Voegeli v. Lewis, 568 F.2d 89, 96-97 (8th Cir. 1977); Weiss v. Chrysler Motors Corp., 515 F.2d 449 (2d Cir. 1975). 
however, there is substantial prejudice or surprise the court should inquire whether a continuance, added discovery, taxing of certain costs, e.g., for rebuttal witnesses, or some other device can cure the prejudice without unduly burdening the innocent party.

If a device is found that will cure the prejudice, the court must still determine the extent to which deviation from the pretrial order would impair the efficient trial of the case or disrupt the court's calendar. Although a cure can be found in inany instances, if the effect is to delay the case substantially or seriously disrupt the court's calendar, then allowing the deviation will defeat the purposes of the pretrial rules. Cases will drag on unnecessarily, judicial time will be wasted, litigants in other cases will be inconvenienced, and attorneys will no longer sense the urgency of complying with the pretrial order.

Finally, the trial judge should consider the offering party's reason for not histing the evidence at the proper time. Even if there is little prejudice, or the prejudice can be annelioriated without sacrificing efficiency, I feel strongly that no inodification should be allowed where its necessity arose from bad faith or gross neghigence by the party seeking modification, or froin a mistaken tactical decision inade by his attorney.

My sense is that atteinpts to deviate from the pretrial order arise, not only froin carelessness, but from tactical choices made early in the proceedings which later prove to be ill-advised. For example, a party may, at the pretrial stage, beheve that the cost of an expert witness is prohibitive. He inay well have discussed this decision with his attorney. At trial, however, the attorney may see that an expert will, after all, be useful, and he may then seek leave to call the expert even though that witness was not nained in the pretrial order.

Such leave should usually be denied. The opposing party, in reliance on the pretrial order, will have structured his case on the assuniption that witnesses not histed in the pretrial order will not be called. Quite often, allowing the evidence will inean further delays-and restructuring of the court's own calendar - so as to afford the opponent of the evidence a fair opportunity for discovery as to the unlisted witness. In addition, the opponent may seek to call additional rebuttal witnesses to meet the unexpected evidence. In short, if deviation from the pretrial order is too hiberally allowed, the purpose of pretrial is utterly defeated, and the time and expense spent on pretrial will have been wasted.

There are, of course, situations in which an attorney's pretrial stipnlation resulted from simple neglect, when a tactical choice turns out to have been so ill-advised that the ninocent chent should be relieved of its consequences, or when later-discovered evidence or other changed 
circumstances warrant deviation from the pretrial order. I have frequently permitted such deviation, despite my belief in vigorous enforcement of pretrial orders. Although an attorney's simple neglect may justify deviation from the pretrial order, especially if the attorney is inexperienced, this deviation must be considered in light of the court's ability to minimize the detrimental effect to the opposing party. ${ }^{105}$ The party whose attorney is delinquent generates quick sympatly, and it is easy to forget that special concessions for that party usually cost the better-represented party time and money.

The question whether to allow deviation from the pretrial order requires the judge very delicately to balance the competing interests of the opposing parties and society's interest in an efficient and smoothly running judicial system. Ultimately, a judge must rely on his instincts - on his "feel" for the case-for the answer to this difficult question. The matter is therefore properly left to the trial courts' discretion.

\section{Choosing Other Appropriate Sanctions for Violations of Pretrial Orders}

Disobedience of pretrial rules may call for more than a refusal to admit evidence. Where a party has, for example, failed to meet scheduled deadlines or to cooperate witl discovery, sanctions for disobedience inust be considered. In deciding between dismissal and monetary sanctions, two primary considerations often collide. Monetary sanctions for violations of pretrial rules are less drastic and are often favored because they enable a judge to minimize the burden on an innocent client. However, a judge must also weigh the hardship and expense to the opposing party and considerations of judicial efficiency in the balance. Solnetimes these considerations will warrant the imposition of sanctions even when an innocent client will necessarily feel their force.

The first sanction, dismissal, is a rather draconian remedy. It should be resorted to only if the party himself is partially at fault or if the attorney's repeated violations of pretrial orders have inade it all but impossible to prosecute or defend the action. In the latter event, the court might consider notifying the client himself that he must appear within a specified time, either pro se or represented by a new attorney, or suffer dismissal. Justice Black's eloquent dissent in Link $\nu$. Wabash ${ }^{106}$ persuades me that dismissal without such prior notice can be terribly unfair to the blanneless client. Where the client himself is blameless, a case should be dismissed outright only where the viola-

105. See, e.g., Meyers v. Pennypack Woods Home Ownership Ass'n, 559 F.2d 894, 904-05 (3d Cir. 1977).

106. See notes 71-76 and accompanying text supra. 
tions have caused irremediable prejudice-for example, where they have made it impossible to proceed for so long that crucial evidence has become stale or unavailable.

In brief, then, three factors should be considered by a court in determining whether to dismiss a case because of violations of pretrial rules and orders. Judges should consider the degree of personal responsibility borne by the party against whom relief is sought, the extent to which the violations have prejudiced the aggrieved party seeking dismissal or have made the case uunecessarily burdensome to the court, and the extent to which any prejudice to the aggrieved party can be minimized by such devices as taxing costs caused by the violation to the offending party.

Monetary charges, a much less severe sanction than dismissal or default, are commonly imposed for violations of pretrial orders. There are two general forms of monetary sanctions: compensatory damages for costs or attorney's fees, and punitive fines. It seems reasonable that a party who has been imconvenienced by his opponent's violation of a pretrial order or rule should be entitled to recover his costs and attorney's fees. Rule 16, however, is completely silent on the subject of sanctions. Many judges seek guidance in Rule 37, which provides sanctions for failure to cooperate in discovery. ${ }^{107}$ Where the prevailing party has failed to properly disclose all of its witnesses or evidence, the court may refuse to tax costs for such witnesses. ${ }^{108}$ There is also authority for assessing the noncomplying attorney with the costs imcurred by the opposing party. ${ }^{109}$ This is an appropriate sanction where one party's lack of preparation or failure to appear causes needless expense and inconvemience to his opponents.

It is also commonly accepted that judges have the power to impose strictly pumitive fines for violations of pretrial orders. A contrary view, however, was expressed in Gamble v. Pope \& Talbot, Inc., ${ }^{110}$ where the defense attorney had submitted his pretrial memorandum more than ten months late. The trial judge, actimg pursuant to a standing order of the district, ordered defendant to pay all costs imcurred by plaintiffs because of the delay, and also imposed a $\$ 100$ fine on the attorney, payable to the United States. After a hearing en banc, five of seven

107. For a general discussion of discovery sanctions, see Renfrew, Discovery Sanctions: $A$ Judicial Perspective, 67 Calif. L. Rev. 264 (1979). See Friedenthal, supra note 60, at 810 (discussing the strengthening of sanctions in recently amended FED. R. CIV. P. 37).

108. FED. R. Crv. P. 54(d) gives the court broad discretion to deny costs to the prevailing party. See Johns-Manville Corp. v. Cement Asbestos Prods. Co., 428 F.2d 1381, 1385 (5th Cir. 1970).

109. Dove v. CODESCO, 569 F.2d 807, 810 (4th Cir. 1978); Fischer v. Buehl, 450 F.2d 950, 951 (3d Cir. 1971).

110. 307 F.2d 729 (3d Cir.), cert. denied, 371 U.S. 888 (1962). 
Third Circuit judges held that a trial court has no power to impose purely punitive fines in civil litigation, outside the context of contempt proceedings. ${ }^{111}$ Subsequent decisions in several other circuits have rejected the majority loolding in Gamble, ${ }^{112}$ although it still appears to be good law in the Third Circuit. ${ }^{113}$ This conflict may be insignificant, however, since the Gamble court did not prevent the trial court from imposing costs and attorney's fees on the delinquent party. Given the fees charged by attorneys for even two hours of wasted time, the imposition of costs and fees slould be at least as effective a deterrent as a punitive fine. ${ }^{114}$

An order imposing a nionetary sanction for the violation of pretrial rules should be tailored to avoid the possibility that an attorney's innocent client will bear the financial burden. The judge should carefully consider the attorney's explanation for his violation, and, if the fault seeins to rest with the attorney, should frame the order so as to enjoin the attorney from billing his client for the sanction imposed. It is naive to suppose that some firms will not treat such sanctions as overhead costs, eventually passing thein on to their clientele. A partial solution to this problent would be to require the sanctioned attorney to serve his client with a copy of the order. This will msure that the chent knows of the sanction, can guard against being billed for it, and can even discharge his attorney if he feels that the event warrants such action. Although the attorney niight still be able to pass on the financial burden of the sanction as an overhead cost, this need not render the sanction a nullity. If clients are inade aware of the imposition of sucl1 sanctions, and attorneys are thereby made more answerable to their clients, sanctions can liardly fail to have an effect on careless attorneys. Moreover, I believe that lawyers do not take inonetary sanctions so hightly. Most lawyers would not wish to risk the damage a judicial reprimand would entail to their pride, to their professional reputations, and to their credibility with their clients.

Opponents of monetary sanctions may also argue that the imposition of sanctions may ruin any chance of rapport and cooperation be-

111. Id. at 732 .

112. Gamble was explicitly rejected in Martinez v. Thrifty Drug \& Discount Co., 593 F.2d 992 (10th Cir. 1979); In re Sutter, 543 F.2d 1030 (2d Cir. 1976), although neither case dealt with fines for violation of pretrial orders. Instead, both considered the general issue of the power of district courts to levy fines. The dissenting opinions in Gamble were quoted with approval by the Fifth Circuit in Delta Theaters, Inc. v. Paramount Pictures, Inc., 398 F.2d 323, 324 (5th Cir.), cert. denied, 393 U.S. 1050 (1968), and Flaska v. Little River Marine Constr. Co., 399 F.2d 885, 888 (5th Cir.), cert. denied, 392 U.S. 928 (1968).

113. See Banger v. Philadelphia Elec. Co., 419 F.2d 1322 (3d Cir. 1969).

114. Of course, in soune instances failure to obey a pretrial order inay also constitute a violation of the discovery provisions of the Federal Rules of Civil Procedure. The application of Rule 37, authorizing fines in sueh instances, is beyond the scope of this Article. 
tween the opposing attorneys, and therefore lessen the chances for stipulations and settlements. This should not be a serious problem: once one party has sought sanctions, rapport between the attorneys is already ailing -indeed, if a party has been seriously inconvenienced by the other side's disobedience of a pretrial rule, rapport will suffer even inore if the inconvenienced party is left with no remedy. Furthermore, a court's failure to sanction clear violations of its rules can only breed disrespect for the rules and for the judicial system. Courts should therefore not hesitate to impose sanctions for clear and serious violations.

It might further be argued that the free imposition of monetary sanctions will generate "mini-trials" to contest the sanctions, complete with their own pretrial orders, violations of these orders, and yet more sanctions for those violations. In fact, however, sanctions have rarely been challenged. ${ }^{115}$ Imposition of costs usually involves amounts of money not sufficiently great to justify the expense and bad publicity that would be involved im challenging the sanction. Moreover, it is usually quite clear that a violation of a pretrial order has occurred. If, for example, a party fails to appear at a scheduled conference, and offers no satisfactory excuse, there is obviously no need for more than a simple hearing, and little to contest thereafter.

Despite these possible objections to the imposition of sanctions, inost hitigators have urged ine to be more rather than less strict in enforcing pretrial rules. The more respectable attorneys feel honorbound to comply with those rules and feel that their less honorable opponents "get away with murder." When violations of pretrial rules and orders are treated lightly, they feel disadvantaged by having made disclosures without receiving anything in return. They may also be put to the expense of numerous filings and appearances made necessary by the other side's delinquency. It is too easy, they fear, to sympathize with the chent of a delinquent or incompetent attorney at the expense of the chent whose lawyer is vigilant and careful. I believe their complaints are justified, and that if judges were more willing to impose inonetary sanctions for significant violations of pretrial rules, they would less often be driven to impose the extreme sanction of dismissal. Moreover, monetary sanctions, as opposed to outright dismissal, can be tailored to be truly compensatory and to minimize the effect on the innocent client.

Thus, there are several factors a court should consider before imposing monetary sanctions. The court should consider whether there has been a clear violation of its pretrial rules or order, whether the

115. See note 70 and accompanying text supra. 
complaining party has suffered expense or prejudice or the court's efficiency has been impaired, ${ }^{116}$ and whether these harms are readily ascertainable. The court should satisfy itself whether the violation is due, at least in part, to a party's own wilful failure to cooperate or his own negligence, rather than due wholly to the attorney's misconduct. In the latter case, the court should consider ordering the attorney to pay the costs personally.

Ideally, of course, sanctions should rarely be necessary to enforce pretrial rules, but during my years on the trial bench I have observed that disobedience of pretrial rules is all too coinunon. Perhaps this will be true until practitioners sense a new judicial attitude in favor of stricter enforcement, although there are certainly persuasive tools judges may employ short of formal sanctions to encourage cooperation. Attorneys may comply more routinely as they have more experience with pretrial and discover its advantages for them, especially if judges are sensitive to the needs of each case and avoid unduly burdensome requirements.

Moreover, if Rule 16 were amended to explicitly authorize sanctions for violations of pretrial rules and orders, there inight be less hesitation about enforcing coinpliance. Although no one appears to have expressed serious doubt that such enforcement authority exists, some lawyers complain that judges are too timid about enforcing pretrial rules and orders. This timidity, which works to the disadvantage of the comphant attorney, might be overcome by explicit authority in Rule 16 to sanction disobedience of pretrial rules and orders. ${ }^{117}$ In addition, specific mention in Rule 16 of the wide range of sanctions enumerated in Rule 27, including preclusion orders, striking of pleadings, stays, default and dismissal, taxing of costs caused by noncompliance, and even contempt for violation of court orders, might also decrease the tendency to rely only on the drastic sanction of dismissal provided by Rule $41(\mathrm{~b}) .^{118}$

\section{CONCLUSION}

Pretrial management of cases has becoine a necessary device for dealing with our judicial system's bursting calendars. It has proven to

116. But see notes 110-14 and accompanying text supra.

117. This change is being considered by the Advisory Committee on the Federal Rules of Civil Procedure. I wish to express my gratitude to Arthur Miller, the reporter of that committee, for providing ine with working draft proposals for the amendment of Rule 16 (on file with the California Law Review), and for his insightful comments on those proposals.

118. It is likely that the imposition of sanctions under this proposed amendinent would continue to be reviewed under the "abuse of discretion" standard that has traditionally governed review of sanctions under both Rule 37 and Rule 41(b). See notes 70, 78-79, 108-09 and accompanying text supra. 
be an advantage to hitigants and not merely a necessary evil. The scheduling function served by the early status conference has proven to be a particularly effective device for imcreasing the productivity of courts and minimizing the cost of litigation. Moreover, in the pursuit of efficiency we have discovered a way to improve our trials by making them better organized and, I believe, more comprehensible to the lay juror. Pretrial, it is true, eliminates some of the fun of the game by involving the lawyers im a certam amount of drudgery and by eliminating some of the surprises. Pretrial properly focuses the action on the search for truth rather than on gamesmanship. Judge Medma has aptly described this changed emphasis in modern pretrial practice:

In the heyday of Common Law Pleading, when each of the numerous technicalities involved provided the members of the bench and bar with a source of continual intellectual amusenent and pleasure, the sporting theory of justice prevailed. To win a lawsuit by guile and surprise or by the skillful manipulation of mysterious rules, understood only by the elite, was quite the thing to do. The development of pretrial procedure and the formulation of Rule 16 of the Federal Rules of Civil Procedure, and similar provisions in most if not all of the States, represents one of the great Twentieth Century contributions to the improvement of judicial administration and the furtherance of effective, timely justice. One of the prime objectives of this new, but now firmly established procedural device, is to do away with the old sporting theory of justice and substitute a more enlightened policy of putting the cards on the table, so to speak, and keeping surprise tactics down to a minimum. ${ }^{119}$

Judge Medima's optimistic remarks depict the second phase of pretrial-that phase where the trial itself is planned, culminating in the final pretrial conference. Many litigators have found precisely this phase irksome and wasteful. But if judges use the first phase-the status conference- to intervene early, to shape discovery, to schedule the pretrial proceedings, and to tailor those proceedings so that they are not more burdensome than necessary, and if courts become more vigilant im enforcing their pretrial orders, the high hopes for pretrial procedures can be fulfilled. 